\title{
Academic Dishonesty in the Canadian Classroom: Behaviours of a Sample of University Students
}

Rozzet Jurdi, H. Sam Hage, \& Henry P. H. Chow

University of Regina

\begin{abstract}
Academic dishonesty is a persistent problem in institutions of higher education, with numerous short- and long-term implications. This study examines undergraduate students' self-reported engagement in acts of academic dishonesty using data from a sample of 321 participants attending a public university in a western Canadian city during the fall of 2007. Various factors were assessed for their influence on students' extent of academic dishonesty. More than one-half of respondents engaged in at least one of three types of dishonest behaviours surveyed during their tenure in university. Faculty of enrolment, strategies for learning, perceptions of peers' cheating and their requests for help, and perceptions and evaluations of academic dishonesty made unique contributions to the prediction of academic dishonesty. High self-efficacy acted as a protective factor that interacted with instrumental motives to study to reduce students' propensity to engage in dishonest academic behaviours. Implications of these findings for institutional interventions are briefly discussed.

\section{RÉSUMÉ}

Le comportement académique malhonnête persiste dans les institutions d'enseignement supérieur, et ses implications à court et à long terme sont nombreuses. La présente étude examine l'adoption d'un comportement académique malhonnête par des étudiants de premier cycle, grâce aux données d'un échantillon de 321 participants qui fréquentaient une université publique dans une ville de l'ouest canadien à l'automne 2007. Différents facteurs ont été évalués en fonction de leur influence sur l'étendue du comportement académique malhonnête des étudiants. Plus de la moitié des étudiants échantillonnés ont adopté au moins l'un des trois types de comportements malhonnêtes au cours de leur passage
\end{abstract}


à l'université. La faculté à s'inscrire, les stratégies d'apprentissage, la perception quant au comportement tricheur des pairs et quant à leurs demandes d'aide, et les perceptions et évaluations de la malhonnêteté académique constituent des indices uniques pour ce qui est de prédire le comportement académique malhonnête. Un degré élevé d'auto-efficacité, de même que certains motifs essentiels, avaient un effet protecteur dans la réduction de la propension des étudiants à s'engager dans des comportements académiques malhonnêtes. L'article aborde brièvement les conséquences de ces résultats au cours d'interventions en institution d'enseignement.

Increasing emphasis on success and achievement is influencing university students' attitudes toward, and extent of engagement in, academic dishonesty. While a considerable amount of work has been done on academic dishonesty, and its causes and consequences in the United States (see for example, Crown \& Spiller, 1998; McCabe, Treviño, \& Butterfield, 2001; Whitley, 1998), there remains a critical need for studies in the Canadian classroom. A thorough review of the published literature highlights persistent gaps in the existing knowledge base regarding the magnitude of the problem and determinants of academic dishonesty among Canadian university students. This situation is troubling as Canadian colleges and universities are not untouched by problems of academic dishonesty (e.g., Genereux \& McLeod, 1995; Christensen Hughes \& McCabe, 2006a; McCabe, Butterfield, \& Treviño, 2006). One could assert with Côte and Allahar (2007) that "in principle there is nothing wrong with cautious and informed generalization between the two countries on matters related to their institutions of higher education" (p. 189). However, Canada's post-secondary educational system enjoys some uniqueness of its own, and therefore Canadian studies are needed and welcomed.

The implications of academic dishonesty are numerous. It compromises the effectiveness of the educational system, making it difficult for universities and colleges to achieve their educational goals and undermining the efforts of instructors to properly evaluate and address any shortcomings in students' knowledge (Carpenter, Harding, Finelli, Montgomery, \& Passow, 2006; Crown \& Spiller, 1998). Of equal importance are the long-term consequences of academic dishonesty. A plethora of studies shows an association between academic dishonesty and the decision to engage in other unethical behaviours during university and beyond (e.g., Beck \& Ajzen, 1991; Grimes, 2004; Harding, Carpenter, Finelli, \& Passow, 2004; Nonis \& Swift, 2001; Sims, 1993; Whitley \& Keith-Spiegel, 2002). For example, Whitley and Keith-Spiegel (2002) showed that students who cheated in high school continued cheating throughout college, and they later on engaged in acts of dishonesty in the place of work. Similarly, Nonis and Swift (2001) found that students who engaged in dishonest behaviours during college were more likely to engage in dishonest acts in the workplace. Other studies revealed that students who cheat were more likely to lie and shoplift (e.g., Beck \& Ajzen, 1991), abuse alcohol (e.g., Kerkvliet, 1994), and cheat on their taxes (e.g., Fass, 1990). 
Researchers like Carpenter et al. (2006), Chapman, Davis, Toy, and Wright (2004), McCabe and Treviño (1995), Nonis and Swift (2001), and Rakovski and Levy (2007) suggest that the problem of academic dishonesty is a sign of a more pervasive problem; namely, misguided moral principles and low ethical standards in all aspects of students' lives. This problem, in turn, calls for higher learning institutions' greater accountability for the socialization of the future workforce by clearly communicating and explaining specific ethical guidelines to their students. These strategies not only can promote students' academic integrity but can also deter them from engaging in other unethical behaviours while in college and beyond, aiding as such in their "moral development and citizenship behaviours" (Christensen Hughes \& McCabe, 2006b, p. 58).

Some studies point to the relationship between students' perceptions and evaluations of academic dishonesty and their self-reported dishonest academic behaviours. Overall, students who have more lenient attitudes toward cheating and who think cheating is normative are more likely to engage in acts of academic dishonesty compared with students who evaluate cheating less leniently or common (e.g., Bolin, 2004; Carpenter et al., 2006; Chapman et al., 2004; Graham, Monday, O'Brien, \& Steffen, 1994; Jensen, Arnett, Feldman, \& Cauffman, 2002; Jordan, 2001; Michaels \& Miethe, 1989; Kidwell, Wozniak, \& Laurel, 2003; Rakovski \& Levy, 2007). For instance, using a sample of 643 engineering and pre-engineering undergraduates at 11 American institutions, Carpenter et al. (2006) found that the frequency with which students engaged in academic dishonesty is higher for behaviours students defined as "unethical but not cheating" as compared to those they defined as "cheating" for 19 of 20 behaviours examined (p. 190). Similarly, in their study of 1,255 business students at a northeastern business college in the United States, Rakovski and Levy (2007) found a negative correlation between whether students defined a behaviour as a "serious" dishonest act and admitting engagement in that act (p. 473).

What is not clear, though, is the extent to which the same is true in Canada. The present investigation contributes to a small but growing literature on academic dishonesty in Canada. It is one of the few empirical studies to examine the role of a number of theoretically important factors on academic dishonesty. Specifically, this study examines undergraduate students' engagement in dishonest academic behaviours using data from a sample of 321 participants attending a public university in a western Canadian city during the fall of 2007. Because the reviewed literature suggests students' perceptions and evaluations of academic dishonesty may be related to their propensity to engage in these behaviours, the present study also looks at these relationships for this sample of university students. Last but not least, this study explores the impact of a number of individual and situational factors hypothesized to influence students' extent of academic dishonesty. 


\section{DETERMINANTS OF ACADEMIC DISHONESTY}

Academic dishonesty is a complex behaviour influenced by multiple factors (for helpful reviews, see for example Crown and Spiller, 1998; McCabe et al., 2001; Whitley, 1998). The review of the literature provides a reasonable basis for organizing these factors into a tentative conceptual model of academic dishonesty. As illustrated in Figure 1, the model of the determinants of academic dishonesty proposed here accounts for the role of individual and situational factors in predicting students' attitudes and behaviours with respect to academic dishonesty. Individual factors comprise demographic, psychosocial, and academic characteristics of students (Chapman et al., 2004), whereas situational factors refer to circumstantial and contextual characteristics which come to bear on the student to encourage (or inhibit) unethical behavioural decision-making (Ford \& Richardson, 1994). Based on the findings of previous research, the demographic correlates examined here include age and sex. We also look at the impact of two psychosocial factors: degree of religious feelings and self-efficacy beliefs. The academic factors proposed to bear a relationship to academic dishonesty include motives to study, academic major, strategies for learning, and academic achievement. In turn, the situational factors under investigation in the present study are perception of peers' cheating behaviour and peers' request for help cheat. It is useful to understand the individual and situational factors that influence academic dishonesty because interventions aimed at curbing academic dishonesty can be targeted to groups who cheat more or contexts/situations where cheating is supported or encouraged.

Figure 1.

Elaborated Model of the Determinants of Academic Dishonesty

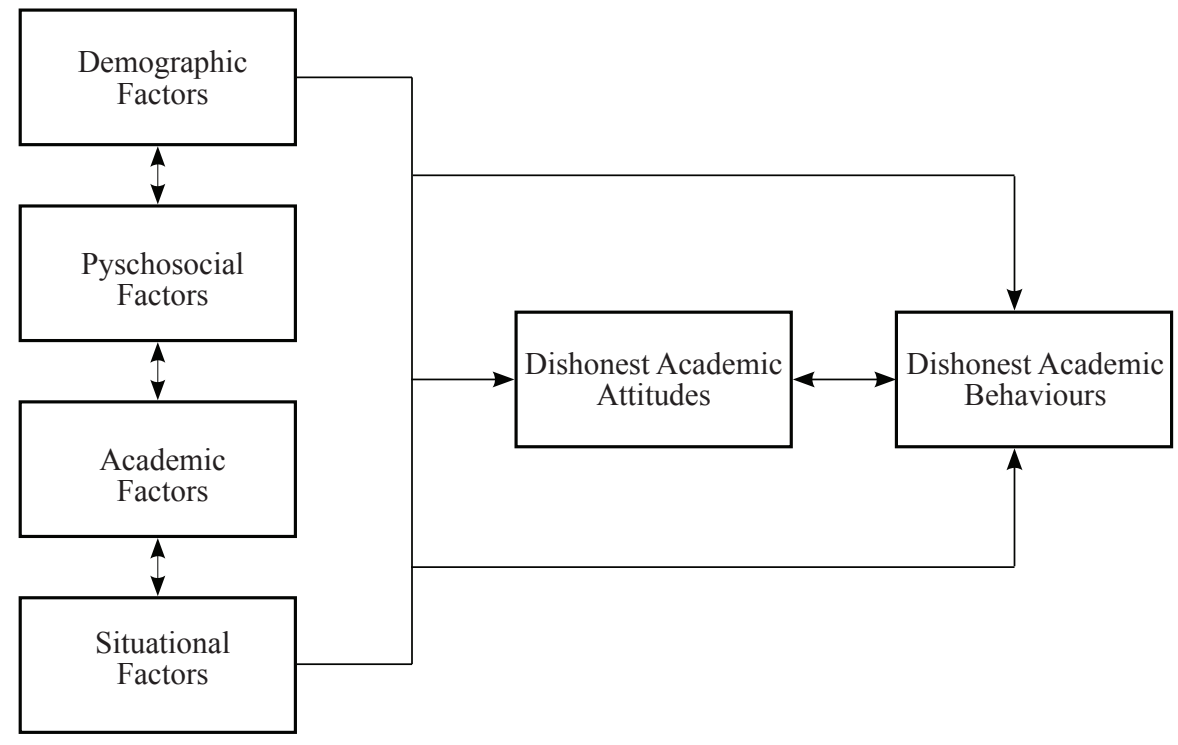




\section{Individual Factors}

The basis of the individual differences approach lies in the identification of personal or dispositional traits that could predict differentials in students' propensity to behave dishonestly (McCabe \& Treviño, 1997). Three sets of theoretical hypotheses associated with this approach will be tested here. The first set of hypotheses assesses relationships between students' dishonest academic behaviours and their demographic characteristics.

Age

Research generally suggests that older students are significantly less likely to cheat than their younger counterparts (e.g., Finn \& Frone, 2004; McCabe \& Treviño, 1997; Newstead, Franklyn-Stokes, \& Arrnstead, 1996; Nonis \& Swift, 2001; Rakovski \& Levy, 2007; Vandehey, Diekhoff, \& LaBeff, 2007). Kohlberg's (1973) theory of moral development offers a theoretical rationalization for this association, explaining that moral reasoning abilities change in predictable ways with age as cognitive abilities develop. Explanations of age differences in academic motivation cannot be ruled out as well, with a growing body of research indicating that older students are more scholastically oriented than their younger counterparts (Newstead et al., 1996). Thus, the following hypothesis will be tested here:

\section{Hypothesis 1: Academic dishonesty will be negatively related to age.}

Sex. Early studies found that male students engaged in more dishonest academic behaviours than female students (e.g., Bowers, 1964), and this relationship was generally attributed to variations in childhood socialization processes of boys and girls and the differential impact of social controls on men and women (Tibbetts, 1997; Whitley, Nelson, \& Jones, 1999). However, Crown and Spiller (1998) in their meta-review of empirical research that spanned over two-and-a-half decades found mixed results. Most pre-1982 studies established sex differences in cheating behaviour (e.g., Leming, 1980); thereafter, some authors became less eager to examine sex differences (e.g., Eskridge \& Ames, 1993), and when they did, they generally found nonsignificant results (e.g., Haines, Diekhoff, LaBeff, \& Clark, 1986), or a higher propensity for females to report academic dishonesty (e.g., Graham et al., 1994) and excuse-making tendencies before cheating (e.g., Ward \& Beck, 1990). Although more recent studies corroborate this pattern of non-significant results between sex and academic dishonesty (e.g., Chapman et al., 2004; Jordan, 2001; Pino \& Smith, 2003), many other studies are still finding that males report engaging in cheating behaviours more often than their female counterparts (e.g., Finn \& Frone, 2004; Jensen et al., 2002; McCabe \& Treviño, 1997; Nonis \& Swift, 2001; Rakovski \& Levy, 2007). Accordingly, we hypothesize that,

Hypothesis 2: Academic dishonesty will be more common among male rather than female students. 
The second set of hypotheses related to the psychosocial factors predicts that students' personal values and core self-evaluations will influence their propensity to behave dishonestly.

Degree of religious feelings. Few studies examined the relationship between academic dishonesty and religious beliefs and behaviours, and those that did revealed somewhat inconsistent findings (e.g., Bloodgood, Turnley \& Mudrack, 2008; Huelsman, Piroch, \& Wasieleski, 2006; Kelley, Young, Denny, \& Lewis, 2005; Michaels \& Miethe, 1989). Exposure to religious teachings can influence individuals' attitudes, values, and behaviours by providing a guiding framework about the appropriateness or inappropriateness of certain beliefs and actions (Bloodgood et al., 2008). Based on the moral and ethical teachings associated with most major religions regarding violation of established standards of behaviour, it seems reasonable to anticipate that students with strong religious backgrounds would be less likely to behave dishonestly because no major religion considers dishonesty (whether academic or otherwise) to be an appropriate behaviour. Indeed, Kelley et al. (2005) indicated that middle and high school students who had the greatest degree of religious commitment were the least likely to report cheating on examinations. Similarly, Bloodgood et al. (2008) found that frequency of attendance at religious services was negatively related to cheating in their sample of 230 undergraduate business students attending a large, state-supported American university. In turn, using a convenience sample of 70 college students in a small southeastern American university, Huelsman et al. (2006) revealed that the inverse correlation between religiosity and academic dishonesty is significant for women but not men. However, Michaels and Miethe (1989) reported that students' level of religiosity was not significantly related to academic misconduct. While research findings are far from unequivocal, the preceding discussion about the potential impact of religious teachings and beliefs on individuals' behaviour leads us to the following hypothesis:

\section{Hypothesis 3: Academic dishonesty will be inversely related to degree of religious} feelings.

Self-efficacy. Previous research found fairly consistent results that estimates of academic dishonesty are lower when students have high expectations of their capabilities to accomplish their goals through personal efforts; that is, they have a high sense of self-efficacy (e.g., Evans \& Craig, 1990; Finn \& Frone, 2004; Jordan, 2001; Kelley et al., 2005; Murdock, Hale, \& Weber, 2001). Self-efficacy, a core construct of Bandura's $(1977,1989)$ social learning theory, refers to the level of control people feel they have over their capacity to successfully achieve their objectives. Self-efficacy influences motivation, affect, thought, and action by conveying to the individual the belief that it is possible to perform challenging tasks by means of taking adaptive action and perseverance. On the basis of the above empirical findings and discussion, we hypothesize that,

Hypothesis 4: Academic dishonesty will be negatively related to self-efficacy beliefs. 
Past studies also examined the effects of a number of academic factors on academic dishonesty. Thus, the last set of individual-based hypotheses is related to these characteristics.

Motives to study. Students' motives - their needs, wants, interests, and desires - to study propel them to enrol in institutions of higher education and affect their attitudes and behaviours while in university (Bogler \& Somech, 2002; Jeffrey, 2009). Students who are scholastically motivated to study have mastery and learning orientations. In sharp contrast, students who have instrumental or social orientations to learning are chiefly motivated by a desire to either acquire a degree for professional mobility or foster social life on campus (Bogler \& Somech, 2002). Academic dishonesty does not help students learn or master academic material; therefore, scholastically motivated students would not view academic dishonesty as a practical strategy for achieving their academic goals (Murdock et al., 2001). Thus, it is safe to argue that students driven by purely scholastic motives to study, striving to satisfy their intellectual curiosity, and thereby concerned with meeting higher-order needs, would be less likely to cheat. This expectation has received empirical support in the findings of prior research. Although measuring this construct in quite different ways, many studies corroborate that students high in scholastic (intrinsic) motivation by placing higher value in education for its own sake are less likely to engage in dishonest academic behaviours (e.g., Angell, 2006; Davy, Kincaid, Smith, \& Trawick, 2007; Eison, Pollio, \& Milton, 1986; Jordan, 2001; Murdock et al., 2001; Newstead et al., 1996; Perry, Kane, Bernesser, \& Spicker, 1990; Rettinger \& Kramer, 2009; Weiss, Gilbert, Giordano, \& Davis, 1993). According to the above arguments and empirical findings, we propose that,

Hypothesis 5: Students who are scholastically motivated by a desire to learn will be less likely to engage in dishonest academic behaviours, whereas their counterparts who are motivated by instrumental or social orientations to learning will be more likely to behave dishonestly.

Academic major. Another academic variable that received increased attention in the literature is students' academic major. Many studies report consistent differences in academic dishonesty according to students' majors, with business students having the highest incidence of academic dishonesty of any college major (e.g., McCabe \& Treviño, 1995; McCabe et al., 2006; Smyth \& Davis, 2003). Among business students, marketing (e.g., Chapman et al., 2004) and management (e.g., Rakovski \& Levy, 2007) students were found to cheat more often than other business majors. McCabe et al. (2006) offered a number of plausible explanations for this pattern, including business students' "bottom-line mentality" and their greater emphasis on success and achievement (p. 295). Thus, we hypothesize that,

Hypothesis 6: Academic dishonesty will be more common among business students than among their counterparts in other faculties. 
Strategies for learning. Relatively fewer studies examined the impact of learning strategies on academic dishonesty (for exceptions, see Anderman, Griesinger, \& Westerfield, 1998; Norton, Tilley, Newstead, \& Franklyn-Stokes, 2001). Learning strategies refer to the specific cognitive processes, practices, or aids to learning that students adopt when studying course material (Arend, 2007; Schunk, 1991). These strategies "direct" students' processing approaches and learning efforts (LindblomYlänne, 2010, p. 64). As such, students' use of different learning strategies accounts for variability in both the amount learned and the type and quality of their learning (Arend, 2007). Biggs (1987) differentiated between deep- and surface-level strategies for encoding and retention of information and task performance. Students who adopt deep learning strategies actively seek to understand the course material, reflect on what it means to them, relate newly learned material to prior knowledge, and examine how this information may apply to new situations (Biggs, 1987, 1999; Jeffrey, 2009). Deep learners seek engagement and understanding of the issues, concepts, and principles they are learning. Conversely, students who adopt surface learning strategies are generally concerned about the time a task takes, think that doing any extra work is unnecessary, and make little effort to relate material to a whole (Biggs, 1987, 1999). They concentrate on the bare essentials for making a good course grade. Put differently, deep learners have a "meaning orientation"; surface learners have a "reproducing orientation" (Richardson, 1990, Table I). Not surprisingly, previous research shows that the deep approach to learning is associated with a wide array of desirable educational outcomes (for a brief review, see for example Lindblom-Ylänne, 2010). For instance, Anderman et al. (1998) found that middle school students who used deep-level cognitive processing strategies when doing their science work were significantly less likely to report cheating. Accordingly, we propose that:

Hypothesis 7: Academic dishonesty will be negatively related to the use of deep-level strategies and positively related to the use of surface-level strategies.

Academic achievement. Research findings on the relationship between academic achievement and academic dishonesty are quite consistent. Using grade point average as a proxy measure, most studies showed that academic achievement was inversely related to academic dishonesty (e.g., Chapman et al., 2004; Diekhoff, LaBeff, Shinohara, \& Yasukawa, 1996; Haines et al., 1986; McCabe \& Treviño, 1997; Newstead et al., 1996; Pino \& Smith, 2003; Rakovski \& Levy, 2007; Vandehey et al., 2007). Consistent with the expectancy-value framework, Leming's (1980) theoretical rationalization for this difference is that low-achieving students "have the most to gain and least to lose, and, therefore, are the most likely to undertake the risks involved in cheating" (p. 86). Put differently, if failure and a low grade results from not engaging in a dishonest academic behaviour, a low-achieving student may deem that the benefit-cost trade-offs would favour cheating and try getting away with it (Whitley, 1998). Accordingly, we hypothesize that:

Hypothesis 8: Academic dishonesty will be inversely related to academic achievement. 


\section{Situational Factors}

The individual differences approach assumes that decisions to behave dishonestly are made in the same way under all circumstances (Rettinger \& Kramer, 2009). Alternatively, the situational differences approach rests on the premise that "students hold qualified guidelines for behavior which are situationally determined. As such, ... college cheating rules for behavior may not be considered rigid but depend on the circumstances involved" (LaBeff, Clark, Haines, \& Diekhoff, 1990, p. 191). Thus, we hypothesize that situational factors will have a strong influence on academic dishonesty.

Perception of peers' behaviour. One situational factor that received attention in the academic dishonesty literature is the role of peers. There is a large theoretical and empirical literature indicating that frequency of academic dishonesty is positively associated with perception of peers' cheating (e.g., Genereux \& McLeod, 1995; Jordan, 2001; McCabe \& Treviño, 1993, 1997; Michaels \& Miethe, 1989; Vandehey et al., 2007) and peers' request for help cheat (e.g., Chapman et al., 2004), and negatively associated with perception of peers' disapproval of cheating (e.g., Beck \& Ajzen, 1991; Carpenter et al., 2006; Diekhoff et al., 1996; Graham et al., 1994; McCabe \& Treviño, 1997; Michaels \& Miethe, 1989; Vandehey et al., 2007) and perceived certainty that classmates will report acts of cheating (e.g., McCabe \& Treviño, 1993; Michaels \& Miethe, 1989; Vandehey et al., 2007).

Speaking from the social learning and differential association perspectives, McCabe and Treviño $(1993,1997)$ argue that dishonesty-related attitudes and behaviours of peers can influence other students by creating a normative climate that makes acts of academic dishonesty more easily justified and by giving students ideas about how to cheat and the skills necessary to perform the deviant act. If transgressors are not caught and disciplined, academic dishonesty is internalized by other students, reinforcing the belief that dishonesty is the norm and thus leading to even more cases of academic dishonesty (Rettinger \& Kramer, 2009). In turn, the amount of undetected cheating going on around them along with the negative feelings associated with perceptions of an unfair competitive arena can incite otherwise honest students to cheat to remain academically competitive (Rettinger \& Kramer, 2009). According to the above findings and arguments, we propose the following two hypotheses:

Hypothesis 9: Academic dishonesty will be positively related to perception of peers' cheating behaviour.

Hypothesis 10: Academic dishonesty will be positively related to peers' request for help cheat in exams or course assignments.

\section{Attitudinal Factors}

Attitudes toward cheating were identified as an important set of correlates of cheating in a meta-analysis of 107 studies published between 1970 and 1996 
(Whitley, 1998). Attitudinal factors offer us the opportunity to better understand the psychological and motivational processes underlying students' dishonest academic behaviours (Bolin, 2004; Haines et al., 1986). In line with the rational choice perspective that people behave in ways consistent with their personal perceptions and evaluations, it is reasonable to argue that students who hold attitudes or definitions favourable to academic dishonesty will engage in dishonest acts more frequently than their counterparts with more condemnatory attitudes or definitions (Bolin, 2004; Haines et al., 1986; Jensen et al., 2002; Murdock \& Anderman, 2006; Whitley, 1998). Of course, in line with the cognitive dissonance perspective, it is also possible that attitudes toward academic dishonesty are the result of past dishonest behaviours, or even that students' attitudes and behaviours with respect to academic dishonesty are reciprocally determined, supporting some combination of the rational choice and cognitive dissonance perspectives (Bolin, 2004; Jensen et al., 2002). Given the difficulty of ascertaining temporal order and the possible reciprocity these factors have on one another, it is hard to establish a causal relationship between dishonesty-related attitudes and behaviours. The model proposed in Figure 1 therefore does not propose a causal link between attitudes and behaviours. ${ }^{1}$ Despite the difficulty of fully addressing the causality issue, what is clear from prior research is that once we have information on students' perceptions and evaluations of academic dishonesty, we also know something about their propensity to behave dishonestly (e.g., Bolin, 2004; Jensen et al., 2002; Jordan, 2001; Kidwell et al., 2003; Rakovski \& Levy, 2007; Vandehey et al., 2007). On the basis of the preceding discussion, we propose the following two hypotheses:

Hypothesis 11: Academic dishonesty will be positively related to leniency in students' overall perceptions of what actions constitute dishonesty in the academic context.

Hypothesis 12: Academic dishonesty will be positively related to the extent to which students feel academic dishonesty is justifiable given certain circumstances.

\section{METHOD}

\section{Data and Sample}

A total of 321 undergraduate students attending a mid-sized, public university in a western Canadian city took part in a self-administered questionnaire survey aimed at examining students' dishonest academic attitudes and behaviours and their satisfaction with various aspects of campus life. With the co-operation of the faculty members in the Department of Sociology and Social Studies, selfadministered questionnaires were distributed to various classes taught during the fall semester of 2007. Students were informed both in writing and verbally of the nature of the research and their rights to refuse to answer any questions or stop their participation at any time. They were also assured of anonymity and confidentiality. The survey took approximately 20 minutes to complete and no incentive was provided. Although the respondents were recruited from Sociology and 
Social Studies classes, it should be emphasized that these students were officially registered with a number of faculties, including Arts $(n=179,55.8 \%)$, Social Work $(n=42,13.1 \%)$, Business Administration $(n=36,11.2 \%)$, Education $(n=21,6.5 \%)$, Science $(n=19,5.9 \%)$, Kinesiology and Health Studies $(n=13,4.0 \%)$, and Other $(n=10,3.2 \%)$. Ethical approval for this study was obtained from this institution's Research Ethics Board.

Representativeness of the sample to the fall 2007 undergraduate student body population of 10,570 students was evaluated by comparing sample age, sex, and academic major statistics to known university parameters on these characteristics (Office of Research Planning, 2008). In comparison to the university student body as a whole, the sample examined in this study was overrepresented by younger students (sample $M=21.2$ and $S D=4.5$ vs. population $\mu=24.6$ ), females ( $68 \%$ of the sample vs. $61 \%$ of the population), and Arts students (55\% of the sample vs. $31 \%$ of the population). We also assessed our sample comparability in terms of age and sex compositions to the Canadian undergraduate student body. The Postsecondary Student Information System is a large database that collects such information at the national level (Statistics Canada, 2009, 2010). In our sample, $88 \%$ of undergraduate students were between the ages of 17 and 24; across the country, $84 \%$ of undergraduate students in 2007 were 17 to 24 years old (Statistics Canada, 2010, Description for Chart 3). During the academic year 2007/2008, females represented only $58 \%$ of the national undergraduate student body, compared with $68 \%$ in our sample (Statistics Canada, 2009, p. 2). Therefore, the characteristics of this sample make it inappropriate to generalize findings of the present study to the entire undergraduate student body at this university or nationally.

\section{Analytical Procedures}

On a five-point scale, students rated the frequency with which they engaged in three different forms of academic dishonesty since starting university $(1=$ never to $5=$ more than 10 times). The behaviours pertained to cheating during examinations, plagiarism on written assignments, and falsification. ${ }^{2}$ To create a composite measure of academic dishonesty, we added and averaged frequencies across the three behaviours so that higher scores indicate a greater frequency of engagement in academic dishonesty. The new composite academic dishonesty measure ranges between 1 and 5, with 1 representing no self-reported academic dishonesty of any kind, and 5 representing frequent academic dishonesty across all categories described (Behaviour). Because the new composite variable had a significant positive skew, the variable was transformed prior to analysis using the natural log transformation.

To examine the relationship between students' perceptions and evaluations of academic dishonesty and their propensity to engage in academic dishonesty, this study also includes two attitudinal variables. Students' Perceptions of What Constitutes Academic Dishonesty uses 17 behavioural acts to assess the extent to 
which participants considered each act to be dishonest in an academic setting and is measured using a five-point Likert scale $(1=$ extremely dishonest to $5=$ not at all dishonest). The survey items employed here were originally developed by Lee, Foster, and Kern (2001) to measure business students' perceptions and attitudes toward dishonesty in the academic context (as cited in Grimes, 2004). From these items, we developed a composite index measuring overall students' perceptions by adding and averaging the individual students' responses to the 17 items (Attitude1). Because the new composite variable had a significant positive skew, the variable was transformed prior to analysis using the natural log transformation.

Evaluation of the Acceptability of Academic Dishonesty is measured using five items assessing the extent to which students feel academic dishonesty is justifiable given certain disabling and opportunistic situational circumstances. We created a composite measure of acceptability of academic dishonesty by adding and averaging the five items (Attitude2), with a score of 1 indicating unacceptability of academic dishonesty under any scenario, and a score of 5 indicating acceptability of academic dishonesty under all scenarios.

Table 1 presents the operational definition of the predictors considered in the analyses. A number of scales were constructed. Factor analysis was used to examine the underlying structure of these scales. We checked the data to ensure the necessary assumptions for principal component analysis were met; namely, most inter-item correlation coefficients are above .30, the Kaiser-Meyer-Olkin (KMO) measure of sampling adequacy is above .60 , and the Bartlett test of sphericity is statistically significant. Only factors with an eigenvalue of 1.0 or above were retained for investigation (Pallant, 2005). Once the factors for each subscale were identified, the factors were rotated using varimax method (Pallant, 2005). Factor scores were computed using the Anderson-Rubin method (Tabachnick \& Fidell, 2007). Once the factor scores were computed, skewed factor scores were transformed as needed. ${ }^{3}$

Table 2 presents means, standard deviations, Chronbach's alpha coefficients where applicable, and intercorrelations for all variables used. Several of the predictors are fairly highly correlated. The inclusion of these variables without further manipulation in a regression would make regression coefficients unstable and inflate standard errors. We used a modified Gram-Schmidt procedure to orthogonalize all variables to eliminate their cross correlations and make their contributions to the estimation mutually independent ${ }^{4}$ (Golub \& Van Loan, 1996). The "orthog" command in Stata 9.1 was employed to generate the orthogonalized variables. The last stage of the data analyses evaluates the relative explanatory power of each subset of independent variables over and above the influence of previous variables in accounting for the variance in (log of) students' self-reported academic dishonesty. Hierarchical multiple linear regression was used in recognition of both theoretical differences and temporal order of the blocks of variables. These computations were conducted with SPSS for Windows version 15. Cases with missing information on any of the variables included in the model were excluded from the analysis. 
Table 1.

Definitions of the Predictors Considered in the Analyses

\section{Variable Label and Explanation}

\section{Demographic Variables}

- Sex, a discrete, nominal variable. Female is the reference category.

- Age, a continuous, ratio variable that inquired about exact age at the time of the survey.

\section{Psychosocial Variables}

- Religious Feelings, a five-point Likert-type item ranging from $1=$ strongly disagree to $5=$ strongly agree that asked respondents to rate the importance of religion in their life.

- Self-efficacy, assessed using five items ranging from $1=$ strongly disagree to $5=$ strongly agree from the Personal Evaluation and Attitudes Scale, a shorter version of Schwarzer and Jerusalem's (1995, p. 35-37) General Self-Efficacy Scale. Factor analysis confirmed these items measured a single construct (KMO statistic $=.831$; Bartlett's test $=671, d f=10$ and $p=.000)$, with all items loading into a single factor (eigenvalue $=3.1$ ) that accounted for $62.1 \%$ of variance.

\section{Academic Variables}

- Motives to Study, assessed using The Academic Motivation Scale, a nine-item Likert-type instrument ( 1 = very unimportant to 5 = very important) based on Shapira and Etzioni-Halevy's (1973) Motive to Study Scale (as cited in Bogler \& Somech, 2002, p. 247). Similar to Bogler and Somech's (2002) findings, initial extraction through principal components produced three factors (KMO statistic $=.734$; Bartlett's test $=950.97, d f=36$ and $p=.000)$, extracted and rotated using varimax rotation. The first factor (eigenvalue $=3.1$ ), termed "Scholastic", was composed of three items with fairly high factor loadings: Intellectual challenge and interest (.89), The will to expand my knowledge (.88), and The desire for self-fulfillment (.77). It accounted for $34.4 \%$ of the variance. The second factor (eigenvalue $=1.9$ ), termed "Instrumental", included three items with equally high factor loadings: The desire to acquire a profession (.88), The desire to achieve a high-status and well-paid job (.86), and The desire to earn a university degree (0.63). This factor accounted for an additional $21 \%$ of the variance. The third factor (eigenvalue $=1.3$ ), termed "Social or Collegiate", was composed of three items that accounted for an additional $14 \%$ of the variance: The desire to be associated with a highstatus group of individuals (.73), The desire to meet my significant other (.77), and The desire to be publicly and politically active (0.69).

- Faculty of Enrolment, a six-category nominal variable. Arts is the reference category.

- Strategies for Learning, assessed using Approaches to Learning Scale, a six-item instrument which measures students' use of study skills and strategies using Likert-type items, ranging from $1=$ strongly disagree to $5=$ strongly agree. This scale is based on an abridged version of Biggs' (1987, p.132-133) Study Process Questionnaire. Like Biggs, two factors were identified, which together accounted for $58.9 \%$ of the variance $(\mathrm{KMO}$ statistic $=.646$; Bartlett's test $=317.48, d f=15$ and $p=.000)$. These were extracted and rotated using varimax rotation. Factor 1, "surface learning strategy," accounted for $36.3 \%$ of variance (eigenvalue $=2.2$ ) and included three items with high factor loadings: I think browsing around is a waste of time, so I only study seriously what is given out in class (.85), I generally restrict my study to what is specially set out as I think it is unnecessary to do anything extra (.79), and I learn best from instructors who work from carefully prepared notes and highlight the major points in class (.64). Factor 2 , "deep learning strategy", accounted for $22.6 \%$ of variance (eigenvalue $=1.4$ ) and was also composed of three items with fairly high loadings: I try to relate what I learned in one subject to that in another (.76), While I am studying, I often think of real life situations to which the material that I am learning would be useful (.75), and I find I have to do enough work on a topic so that I can form my own point of view before I am satisfied (.72).

- Academic Achievement, a self-reported overall grade point average on a six-point scale $(1=$ under $50 ; 2=50-59 ; 3=60-69 ; 4=70-79 ; 5=80-89 ; 6=90-100)$.

\section{Situational Variables}

- Peers' Cheating Behaviour, assessed using a four-point Likert scale item ( $1=$ zero times to $4=$ seven or more times) that asked respondents how often they observed others cheat.

- Peers' Request for Help, measured with two items that asked respondents whether they have been asked to help someone cheat on an exam or a course assignment. 


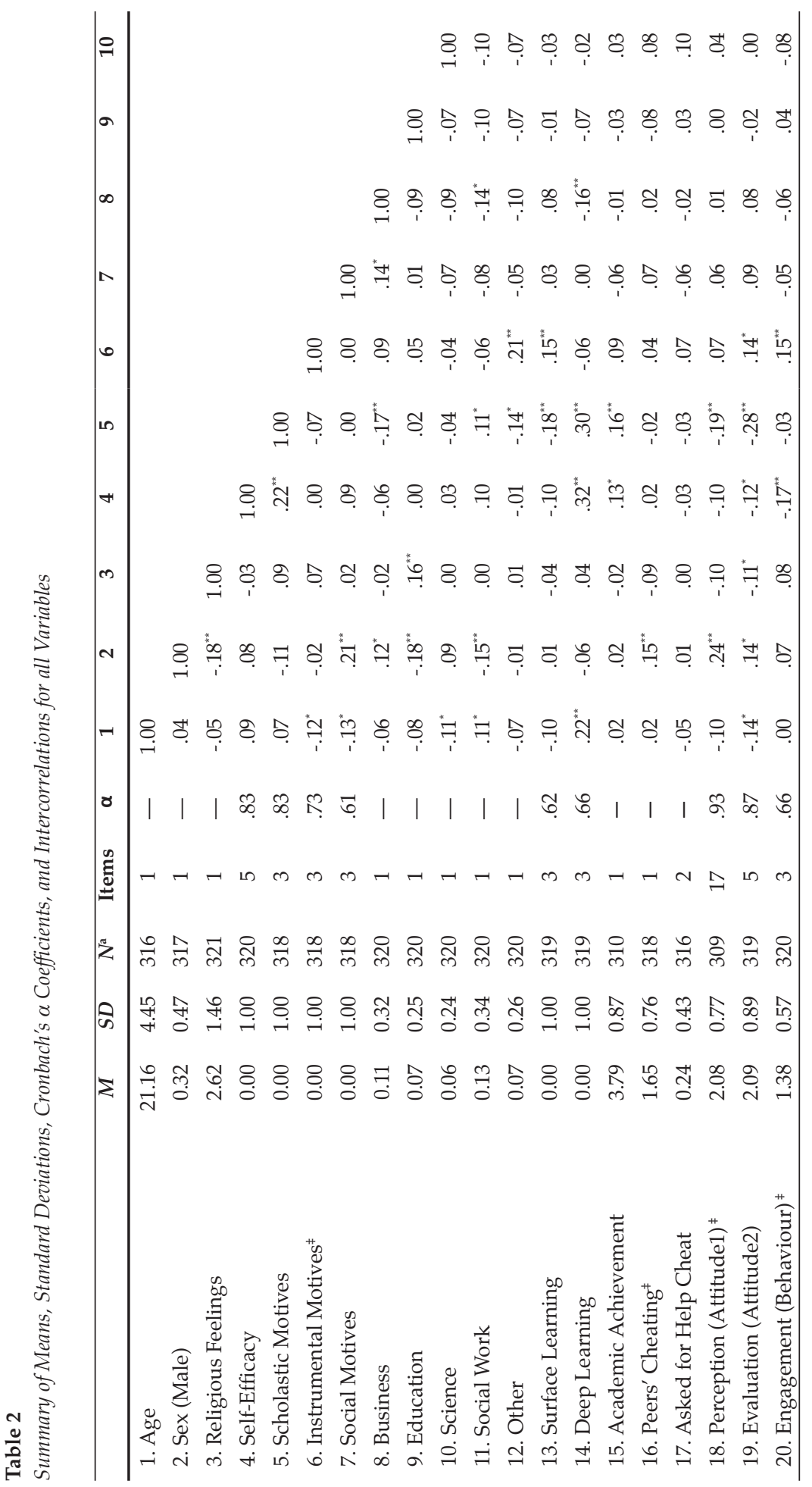




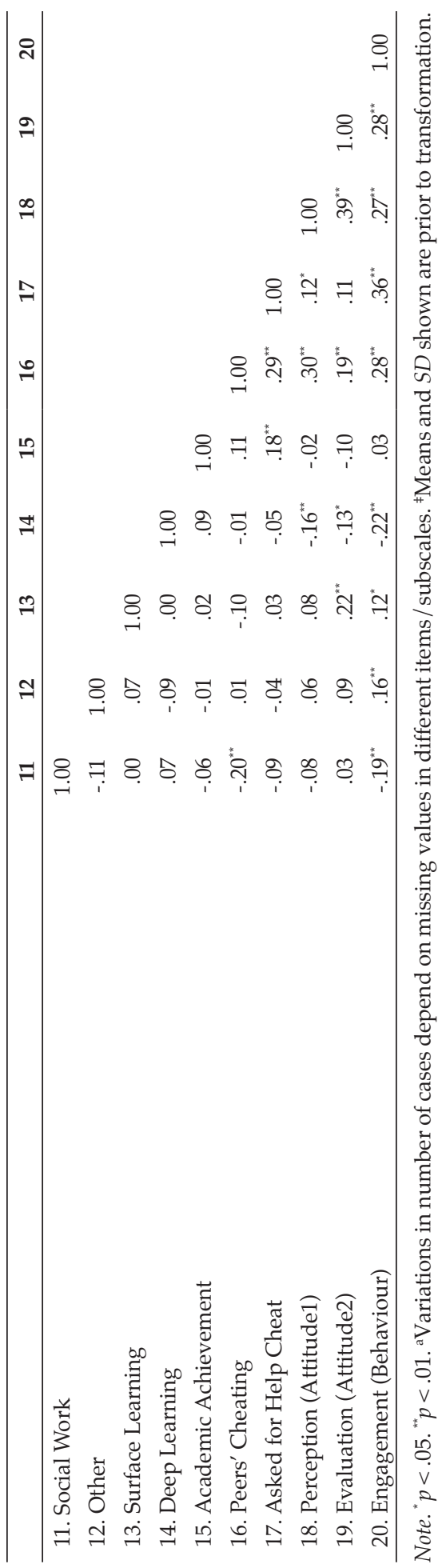




\section{RESULTS}

\section{Dishonest Academic Behaviours}

Students engaged in a variety of dishonest academic behaviours since starting university (Table 3). Three of 10 students reported "plagiarism on written assignments" during their tenure at the university, and slightly over a quarter reported "cheating during examinations" and "falsification." Nevertheless, when counting the total number of students who admitted academic dishonesty of any form, more than one half $(52.5 \%)$ of the students engaged in at least one of the three types of academic dishonesty surveyed during their tenure at university. Of these, the majority reported behaving dishonesty only "seldom" or "occasionally."

Table 3.

Extent of Academic Dishonesty

\begin{tabular}{|c|c|c|c|c|c|c|c|c|}
\hline \multirow{2}{*}{$\begin{array}{l}\text { Type of Academic } \\
\text { Dishonesty }\end{array}$} & \multicolumn{5}{|c|}{ Percent (\%) who reported: } & \multirow[t]{2}{*}{$\mathbf{M}$} & \multirow[t]{2}{*}{$S D$} & \multirow[t]{2}{*}{$\mathrm{N}^{\mathrm{a}}$} \\
\hline & Never & Seldom $^{1}$ & Occasionally $^{2}$ & Often $^{3}$ & $\begin{array}{c}\text { Very } \\
\text { Often }^{4}\end{array}$ & & & \\
\hline Cheating & 73.2 & 21.8 & 3.1 & 1.2 & 0.6 & 1.34 & 0.66 & 321 \\
\hline Plagiarism & 70.1 & 23.1 & 4.4 & 1.9 & 0.6 & 1.40 & 0.72 & 321 \\
\hline Falsification & 74.7 & 16.6 & 4.7 & 3.1 & 0.9 & 1.39 & 0.80 & 320 \\
\hline $\begin{array}{l}\text { Overall Composite } \\
\text { Index (Averaged) }\end{array}$ & & & & & & 1.38 & 0.57 & 320 \\
\hline
\end{tabular}

Note. ${ }^{1}$ Once or twice; ${ }^{2}$ Three or four times; ${ }^{3}$ Five to ten times; ${ }^{4}$ More than 10 times. ${ }^{a}$ Variations in number of cases depend on missing values in different items.

\section{Relationship Between Attitudes and Behaviours}

Table 4 summarizes the relationship between students' perceptions of what constitutes dishonesty in the academic setting and their self-reported academic dishonesty. The data revealed a directional difference in the responses. Admitted cheaters had higher item-mean scores for each of the 17 scenarios when compared with their non-cheater counterparts, implying greater disagreement that these situations were dishonest in the academic setting. An item by item $t$-test analysis revealed that only 10 of these differences were statistically significant at the .05 level (items 3, 6-10, 12, and 14-16). Total overall perception scores differed significantly between the two groups as well $(t=-3.17, p<.010)$. The correlation between students' overall perceptions of what constitutes dishonesty and the frequency of their self-reported academic dishonesty was also examined (Table 2), and found to have a positive and statistically significant, albeit moderate, association $(r=0.27$, $p<.001)$. 
Table 4.

Students' Perceptions of What Constitutes Dishonesty in the Academic Setting: Non-Cheaters vs. Cheaters

\begin{tabular}{|c|c|c|c|c|c|}
\hline \multirow[t]{2}{*}{ Behaviour } & \multicolumn{2}{|c|}{ Non-Cheaters } & \multicolumn{2}{|c|}{ Cheaters } & \multirow[t]{2}{*}{$t$-test (sig } \\
\hline & Mean & $S D$ & Mean & $S D$ & \\
\hline 1. Completing an exam for another student & 1.31 & 0.89 & 1.51 & 1.15 & $\begin{array}{c}-1.73 \\
(p=.084)\end{array}$ \\
\hline 2. Purchasing a paper to turn in as his or her own & 1.34 & 0.91 & 1.55 & 1.12 & $\begin{array}{c}-1.83 \\
(p=.068)\end{array}$ \\
\hline 3. Writing a paper for another student & 1.44 & 0.96 & 1.68 & 1.12 & $\begin{array}{c}-2.02 \\
(p=.044)\end{array}$ \\
\hline $\begin{array}{l}\text { 4. Looking at another student's paper during an } \\
\text { exam }\end{array}$ & 1.46 & 1.02 & 1.65 & 1.02 & $\begin{array}{c}-1.60 \\
(p=.111)\end{array}$ \\
\hline 5. Using cheat sheets during an exam & 1.50 & 1.03 & 1.69 & 1.13 & $\begin{array}{c}-1.50 \\
(p=.134)\end{array}$ \\
\hline $\begin{array}{l}\text { 6. Asking another student to take an exam on your } \\
\text { behalf }\end{array}$ & 1.48 & 0.97 & 1.79 & 1.19 & $\begin{array}{c}-2.57 \\
(p=.011)\end{array}$ \\
\hline 7. Selling a paper to another student & 1.60 & 1.00 & 1.92 & 1.22 & $\begin{array}{c}-2.50 \\
(p=.013)\end{array}$ \\
\hline $\begin{array}{l}\text { 8. Allowing others to look at one's paper during } \\
\text { an exam }\end{array}$ & 1.62 & 1.03 & 1.90 & 1.09 & $\begin{array}{c}-2.41 \\
(p=.016)\end{array}$ \\
\hline $\begin{array}{l}\text { 9. Providing instructor a false reason for missing } \\
\text { an exam }\end{array}$ & 1.74 & 1.06 & 1.99 & 1.09 & $\begin{array}{c}-2.15 \\
(p=.032)\end{array}$ \\
\hline $\begin{array}{l}\text { 10. Receiving questions for an exam prior to taking } \\
\text { it }\end{array}$ & 2.07 & 1.27 & 2.35 & 1.25 & $\begin{array}{c}-2.03 \\
(p=.043)\end{array}$ \\
\hline $\begin{array}{l}\text { 11. Using direct quotes without giving proper refer- } \\
\text { ences }\end{array}$ & 2.08 & 1.13 & 2.33 & 1.16 & $\begin{array}{c}-1.93 \\
(p=.550)\end{array}$ \\
\hline $\begin{array}{l}\text { 12. Doing less work than one's share in a group } \\
\text { project }\end{array}$ & 2.05 & 0.96 & 2.36 & 1.04 & $\begin{array}{c}-2.75 \\
(p=.006)\end{array}$ \\
\hline 13. Using sources not included in the references & 2.58 & 1.26 & 2.69 & 1.13 & $\begin{array}{c}-0.82 \\
(p=.412)\end{array}$ \\
\hline $\begin{array}{l}\text { 14. Giving test information to someone absent from } \\
\text { the test }\end{array}$ & 2.56 & 1.30 & 2.92 & 1.23 & $\begin{array}{c}-2.58 \\
(p=.010)\end{array}$ \\
\hline $\begin{array}{l}\text { 15. Submitting the same paper for more than one } \\
\text { course }\end{array}$ & 2.60 & 1.26 & 2.93 & 1.33 & $\begin{array}{c}-2.24 \\
(p=.026)\end{array}$ \\
\hline $\begin{array}{l}\text { 16. Intending to use cheat sheets but not actually } \\
\text { using them }\end{array}$ & 2.85 & 1.28 & 3.20 & 1.17 & $\begin{array}{c}-2.60 \\
(p=.010)\end{array}$ \\
\hline $\begin{array}{l}\text { 17. Increasing margins / font size to make paper } \\
\text { look longer }\end{array}$ & 2.78 & 1.09 & 2.99 & 1.13 & $\begin{array}{c}-1.71 \\
(p=.089)\end{array}$ \\
\hline $\begin{array}{l}\text { Overall Composite Index } \\
\text { (Averaged) }\end{array}$ & 1.93 & 0.75 & 2.21 & 0.76 & $\begin{array}{c}-3.17 \\
(p=.002)\end{array}$ \\
\hline
\end{tabular}

Note. Non-cheaters $(n)=151$; Cheaters $(n)=166$. 
Table 5 summarizes the relationship between students' evaluations of the acceptability of academic dishonesty and their self-reported academic dishonesty. Cheaters had higher levels of acceptability of academic dishonesty given each of the five scenarios surveyed, with all differences being statistically significant. Total acceptability scores differed significantly between the two groups as well $(t=-4.24$, $p<.001)$. Correlations between students' overall evaluations of the acceptability of academic dishonesty and the frequency of their self-reported academic dishonesty were also examined, and found to be moderate but statistically significant $(r=$ $0.28, p<.001)$.

Table 5.

Evaluation of the Acceptability of Academic Dishonesty: Non-Cheaters vs. Cheaters

\begin{tabular}{|c|c|c|c|c|c|}
\hline \multirow[t]{2}{*}{ Motives } & \multicolumn{2}{|c|}{ Non-Cheaters } & \multicolumn{2}{|c|}{ Cheaters } & \multirow[t]{2}{*}{$t$-test (sig) } \\
\hline & Mean & $S D$ & Mean & $S D$ & \\
\hline 1. Heavy academic work load at this university & 2.03 & 1.14 & 2.38 & 1.07 & $\begin{array}{c}-2.83 \\
(p=.005)\end{array}$ \\
\hline 2. Pressure to maintain a scholarship & 2.12 & 1.14 & 2.57 & 1.15 & $\begin{array}{c}-3.52 \\
(p=.000)\end{array}$ \\
\hline 3. Pressure from parents to perform well & 2.07 & 1.14 & 2.47 & 1.20 & $\begin{array}{c}-3.10 \\
(p=.000)\end{array}$ \\
\hline 4. Chance of getting caught is minimal & 1.67 & 0.90 & 2.08 & 1.04 & $\begin{array}{c}-3.77 \\
(p=.000)\end{array}$ \\
\hline 5. Other students are cheating without getting caught & 1.49 & 0.93 & 1.96 & 1.07 & $\begin{array}{c}-4.12 \\
(p=.000)\end{array}$ \\
\hline $\begin{array}{l}\text { Overall Composite Index } \\
\text { (Averaged) }\end{array}$ & 1.88 & 0.86 & 2.29 & 0.88 & $\begin{array}{c}-4.24 \\
(p=.000)\end{array}$ \\
\hline
\end{tabular}

Note. Non-cheaters $(\mathrm{n})=151$; Cheaters $(\mathrm{n})=166$.

\section{Multivariate Analyses}

To assess the relative contributions of the hypothesised predictors on (log of) academic dishonesty, a five-step hierarchical ordinary least-squares multiple linear regression was conducted. In addition to the individual and situational variables defined above, the analyses presented in this section also include interaction terms between the motives to study subscales and the self-efficacy scale. We predicted that students who are motivated by instrumental or social orientations to learning would be more likely to engage in acts of academic dishonesty (Hypothesis 5). Preliminary analyses revealed that the relationship between motives to study and propensity to behave dishonestly is complex, being moderated by self-efficacy beliefs. This study extends prior research by examining how self-efficacy interacts with motives to study to influence academic dishonesty. The results are summarized in Table 6.

In Block 1, the demographic predictors were entered. None of these predictors made a unique contribution to the prediction of academic dishonesty. After the Block 2 variables were included, the overall model explained $4.4 \%$ of the variance in ( $\log$ of) academic dishonesty $\left(F(4,285)=3.307, p<.050, R^{2}=.044\right)$. The psycho- 
Table 6.

Summary of Hierarchical Regression Analysis for (Log of) Extent of Engagement in Dishonest Academic Behaviours

\begin{tabular}{|c|c|c|c|c|c|c|c|c|}
\hline Block & Predictor Variables & $F$ & $R$ & $R^{2}$ & $\Delta R^{2}$ & B & $t$-value & Beta \\
\hline \multirow[t]{5}{*}{1} & Demographic Factors & 0.353 & .050 & .002 & .002 & & & \\
\hline & Age & & & & & -.002 & -0.304 & -.015 \\
\hline & Gender & & & & & & & \\
\hline & Female (r) & & & & & & & \\
\hline & Male & & & & & .007 & 0.960 & .047 \\
\hline \multirow[t]{3}{*}{2} & Psychosocial Factors & $3.307^{*}$ & .211 & .044 & $.042^{* *}$ & & & \\
\hline & Religious Feelings & & & & & .007 & 1.097 & .054 \\
\hline & Self-Efficacy & & & & & $-.027^{* * *}$ & -4.012 & -.197 \\
\hline \multirow[t]{14}{*}{3} & Academic Factors & $3.300^{*+* *}$ & .391 & .153 & $.109^{* * * *}$ & & & \\
\hline & Scholastic Motives & & & & & .005 & 0.744 & .037 \\
\hline & Instrumental Motives & & & & & $.016^{*}$ & 2.394 & .118 \\
\hline & Social Motives & & & & & -.008 & -1.246 & -.061 \\
\hline & Faculty & & & & & & & \\
\hline & Arts (r) & & & & & & & \\
\hline & Business & & & & & -.012 & -1.760 & -.087 \\
\hline & Education & & & & & .005 & 0.729 & .036 \\
\hline & Science & & & & & -.008 & -1.199 & -.059 \\
\hline & Social Work & & & & & $-.023^{* * * *}$ & -3.457 & -.170 \\
\hline & Other ${ }^{\ddagger}$ & & & & & .012 & 1.811 & .089 \\
\hline & Surface Learning Strategy & & & & & $.016^{*}$ & 2.411 & .119 \\
\hline & Deep Learning Strategy & & & & & $-.022^{* *}$ & -3.241 & -.159 \\
\hline & Academic Achievement & & & & & .004 & 0.646 & .032 \\
\hline \multirow[t]{4}{*}{4} & Interaction Terms & $3.523^{*+*+}$ & .435 & .190 & $.037^{* *}$ & & & \\
\hline & Scholastic*Self-efficacy & & & & & -.008 & -1.129 & -.056 \\
\hline & Instrumental*Self-efficacy & & & & & $-.023^{*+*+}$ & -3.371 & -.166 \\
\hline & Social*Self-efficacy & & & & & .011 & 1.573 & .077 \\
\hline \multirow[t]{5}{*}{5} & Situational Factors & $7.196^{4 *+*}$ & .590 & .349 & $.159^{* * * *}$ & & & \\
\hline & Peers' Cheating & & & & & $.037^{\text {tan }}$ & 5.416 & .267 \\
\hline & Request for Help Cheat & & & & & & & \\
\hline & No $(r)$ & & & & & & & \\
\hline & Yes & & & & & $.041^{* * * *}$ & 6.024 & .296 \\
\hline
\end{tabular}

Note. $\mathrm{B}=$ Unstandardized coefficients. Beta $=$ Standardized coefficients. $(\mathrm{r})=$ Reference category. ${ }^{*} p<.05 .{ }^{* *} \mathrm{p}$ $<.01{ }^{* * * *} \mathrm{p}<.001$. ${ }^{*}$ Other includes Kinesiology and Health Sciences, Fine Arts, and Other faculties. $N=290$. All predictors have been orthogonalized. 
social variables, therefore, explained $4.2 \%$ of the total variance, after controlling for the effects of demographic variables $\left(\Delta R^{2}=.042, p<.010\right)$. Of the psychosocial variables, only a student's sense of self-efficacy was found to be significantly and inversely related to the dependent variable, after controlling for the demographic variables ( $\beta=-.197, p<.001$ ). This result is consistent with Hypothesis 4 .

After the Block 3 variables were included, the overall model explained 15.3\% of the variance in (log of) academic dishonesty $\left(F(15,274)=3.300, \mathrm{p}<.001, R^{2}=\right.$ .153). The academic variables, therefore, explained about $11 \%$ of the total variance, after controlling for the effects of demographic and psychosocial variables $\left(\Delta R^{2}=\right.$ $.109, p<.001)$. As predicted in Hypothesis 5, a high score in the instrumental motives to study subscale was positively related to extent of academic dishonesty $(B=$ $.118, p<.050$ ). Students enrolled in Social Work (as compared with Arts) were significantly less likely to report academic dishonesty $(\beta=-.170, p<.001)$. In line with Hypothesis 7, a high score in the deep learning strategy subscale was found to be inversely related to extent of academic dishonesty $(B=-.159, p<.010)$. Conversely, a high score in the surface learning strategy subscale was found to be positively related to extent of academic dishonesty $(B=.119, p<.050)$.

The cross product terms of the motives to study subscales and self-efficacy, which entered in Block 4, explained an additional 3.7\% of total variance $\left(R^{2}=.190\right.$, $\left.\Delta R^{2}=.037, F(18,271)=3.523, p<.001\right)$. The interaction term between instrumental motives to study and self-efficacy was statistically significant, and its coefficient was in the expected direction. The algebraic sign of this interaction term shows that a high score in the instrumental motives to study subscale in combination with a high score in the self-efficacy scale was associated with a lower propensity to report dishonest academic behaviours $(B=-.166, p<.001)$. Put differently, self-efficacy acted as a "protective factor" (Finn \& Frone, 2004; Pintrich, 2003) that interacted with instrumental motives to study to reduce the extent of academic dishonesty.

In the final step, after controlling for the effects of demographic, academic, psychosocial, and moderating variables, situational variables were added to the model. The overall model explained about $35 \%$ of the variance in (log of) academic dishonesty $\left(F(20,269)=7.196, p<.001, R^{2}=.349\right)$. The situational variables, therefore, accounted for $16 \%$ of total variance $\left(\Delta R^{2}=.159, p<.001\right)$, having the strongest impact on academic dishonesty. Consistent with Hypotheses 9 and 10, both perceptions of peers' cheating behaviour $(B=.267, \mathrm{p}<.001)$ and peers' request for help cheating $(B=.296, \mathrm{p}<.001)$ were highly significant predictors of academic dishonesty.

As we showed in the preceding section, students' perceptions and evaluations of academic dishonesty are related to their propensity to engage in these behaviours. As noted, however, it is hard to establish a causal link between dishonest academic attitudes and behaviours using cross-sectional designs, given the difficulty of establishing temporal order and the possible reciprocity these factors have on one another. While we do not offer to solve this issue here, it is deemed important to examine the impact of students' perceptions and evaluations of academic dishonesty on their self-reported dishonesty. To accomplish this examination, two 
standard multiple regression models were constructed, offering us an opportunity to better understand the attitudinal processes involved in students' dishonest academic behaviours, after controlling for other theoretically relevant predictors. The results are summarized in Table 7.

The model containing the individual and situational factors along with (log of) students' overall perceptions of what constitutes dishonesty in academia (Attitude1) accounted for $37 \%$ of the observed variance in (log of) academic dishonesty $\left(F(21,257)=7.166, p<.001, R^{2}=.369\right)$. In line with Hypothesis 11 , there was a highly significant, positive relationship between leniency in students' overall perceptions of what actions constitute dishonesty in the academic context and the extent of their academic dishonesty, after controlling for other independent variables ( $ß=0.159, p<.010)$. In turn, Model II, containing the individual and situational factors along with students' evaluations of the acceptability of academic dishonesty (Attitude2), accounted for approximately $41 \%$ of the observed variance in the dependent variable $\left(F(21,266)=8.765, p<.001, R^{2}=.409\right)$. After controlling for the individual and situational variables, there was a highly significant and positive relationship between students' evaluations of the acceptability of academic dishonesty and the extent of their academic dishonesty $(B=.251, p<.001)$. This result is consistent with Hypothesis 12. All other predictors retained their previous levels of significance after controlling for each of these attitudinal variables.

\section{SUMMARY AND DISCUSSION}

Similar to the results of five decades of research on American undergraduate students, the current study shows that this mid-sized, public western Canadian university is not untouched by problems of academic dishonesty, with more than one-half of the sampled students having engaged in at least one of three types of dishonest behaviours surveyed during their academic tenure in college. Specifically, three of 10 students reported "plagiarism on written assignments," and slightly over a quarter reported "cheating during examinations" and "falsification." These findings support the work of previous researchers who also found that academic dishonesty is more common on written assignments than tests (e.g., Carpenter et al., 2006; Christensen Hughes \& McCabe, 2006a; Genereux \& McLeod, 1995; Haines et al., 1986). The majority of those who behaved dishonestly reported doing so only seldom (once or twice) or occasionally (three or four times).

The dishonesty estimates from this study are not directly comparable to other Canadian-based studies. For example, there are clear differences in this study's dishonesty estimates and those obtained by Christensen Hughes and McCabe (2006a) using data from about 15,000 undergraduate students enrolled in $11 \mathrm{Ca}-$ nadian higher education institutions. In their study, Christensen Hughes and McCabe (2006a) found that only about two in 10 undergraduate students reported engagement in "serious test cheating behaviour" the year preceding the survey, while slightly over five of 10 students reported engagement in "serious cheating 
Table 7.

Standard Multiple Regression Coefficients for Selected Individual, Situational, and Attitudinal Predictors of (Log of) Extent of Academic Dishonesty

\begin{tabular}{|c|c|c|c|c|c|c|}
\hline \multirow[t]{2}{*}{ Predictor Variables } & \multicolumn{3}{|c|}{ Model I } & \multicolumn{3}{|c|}{ Model II } \\
\hline & B & $t$-value & Beta & B & $t$-value & Beta \\
\hline (Constant) & $.112^{* * * t}$ & 16.378 & & $.110^{* * *+}$ & 17.053 & \\
\hline \multicolumn{7}{|l|}{ Demographic Factors } \\
\hline Age & -.003 & -0.500 & -.025 & -.002 & -0.344 & -.016 \\
\hline \multicolumn{7}{|l|}{ Gender } \\
\hline \multicolumn{7}{|l|}{ Female (r) } \\
\hline Male & .008 & 1.140 & .056 & .004 & 0.670 & .032 \\
\hline \multicolumn{7}{|l|}{ Psychosocial Factors } \\
\hline Religious Feelings & .007 & 0.956 & .047 & .008 & 1.212 & .057 \\
\hline Self-Efficacy & $-.028^{* * * *}$ & -4.154 & -.206 & $-.028^{*+*}$ & -4.274 & -.201 \\
\hline \multicolumn{7}{|l|}{ Academic Factors } \\
\hline Scholastic Motives & .004 & 0.653 & .032 & .007 & 1.130 & .053 \\
\hline Instrumental Motives & $.015^{*}$ & 2.166 & .107 & $.016^{*}$ & 2.407 & .113 \\
\hline Social Motives & -.009 & -1.263 & -.063 & -.008 & -1.188 & -.056 \\
\hline \multicolumn{7}{|l|}{ Faculty } \\
\hline \multicolumn{7}{|l|}{ Arts (r) } \\
\hline Business & -.011 & -1.615 & -.080 & -.011 & -1.685 & -.079 \\
\hline Education & .005 & 0.770 & .038 & .005 & 0.774 & .036 \\
\hline Science & -.008 & -1.234 & -.061 & -.007 & -1.135 & -.054 \\
\hline Social Work & $-.024^{* * * *}$ & -3.478 & -.172 & $-.023^{*+*}$ & -3.595 & -.169 \\
\hline Other & .012 & 1.817 & .090 & .010 & 1.559 & .073 \\
\hline Surface Learning Strategy & $.015^{*}$ & 2.150 & .107 & $.014^{*}$ & 2.208 & .104 \\
\hline Deep Learning Strategy & $-.022^{* *}$ & -3.175 & -.157 & $-.023^{* *}$ & -3.505 & -.165 \\
\hline Academic Achievement & .006 & 0.881 & .044 & .004 & 0.627 & .030 \\
\hline \multicolumn{7}{|l|}{ Interaction Terms } \\
\hline Scholastic*Self-Efficacy & -.002 & -0.258 & -.013 & -.008 & -1.169 & -.055 \\
\hline Instrumental`Self-Efficacy & $-.021^{* *}$ & -3.057 & -.151 & $-.024^{* * *}$ & -3.672 & -.173 \\
\hline Social'Self-Efficacy & .011 & 1.563 & .077 & .010 & 1.583 & .075 \\
\hline \multicolumn{7}{|l|}{ Situational Factors } \\
\hline Peers' Cheating & $.038^{* * * *}$ & 5.482 & .272 & $.037^{* * *}$ & 5.677 & .268 \\
\hline \multicolumn{7}{|l|}{ Request for Help Cheat } \\
\hline Yes & $.041^{*+*+}$ & 6.019 & .298 & $.041^{*+*+}$ & 6.309 & .297 \\
\hline \multicolumn{7}{|l|}{ Attitudinal Factors } \\
\hline Attitude $1^{\Delta}$ & $.022^{* *}$ & 3.210 & .159 & & & \\
\hline Attitude 2 & & & & $.034^{* * * *}$ & 5.317 & .251 \\
\hline F Model & $7.166^{*+* t}$ & & & $8.765^{* * *}$ & & \\
\hline$R$ & .608 & & & .640 & & \\
\hline$R^{2}$ & .369 & & & .409 & & \\
\hline$N$ & 279 & & & 288 & & \\
\hline
\end{tabular}

Note. ${ }^{*} p<.05 .{ }^{* *} p<.01 .{ }^{* * *} p<.001$. $(\mathrm{r})=$ Reference category. $\Delta$ Attitude $1=$ Students' perceptions of what constitutes dishonesty in academia (log of). $\square$ Attitude $2=$ Students' evaluation of the acceptability of academic dishonesty. All predictors have been orthogonalized. 
on written work" (p. 8). Differences in the prevalence rates reported in the present study compared with those found in the aforementioned study are likely due to variations in the conceptualization and operationalization of academic dishonesty. ${ }^{5}$ These discrepancies make it especially difficult to compare and make meaning of differences among the few available Canadian empirical studies.

This study explored the impact of a number of individual, situational, and attitudinal factors related to academic dishonesty. The reviewed literature provided a reasonable basis for organizing these factors into a tentative causal model of academic dishonesty (Figure 1). This study assessed the predictive validity of this conceptual model in relation to undergraduate students' self-reported academic dishonesty. Overall, the regression analyses found that the hypothesized predictors were successful in predicting a moderate amount of variance in the overall measure of academic dishonesty examined here.

Peer-related factors were the most influential predictors of students' selfreported academic dishonesty, lending further support for the influence of situational factors in predicting academic dishonesty. This finding is in line with much of the reviewed literature (e.g., Chapman et al., 2004; Genereux \& McLeod, 1995; Jordan, 2001; McCabe \& Treviño, 1993, 1997; Michaels \& Miethe, 1989; Vandehey et al., 2007). Consistent with Bandura's (1986) social learning theory, we argue that observing peers' cheat or getting asked for help cheat sends the message that cheating is the "norm." When students perceive behaving dishonestly is the norm, engagement in such acts becomes more expected "either to level the playing field or simply because of a contagion effect" (Bloodgood et al., 2008, p. 558).

Another significant finding of this study is that students' engagement in dishonest academic behaviours was influenced by their attitudes toward academic dishonesty. Both students' perceptions and their evaluations of academic dishonesty played critical roles in the prediction of self-reported academic dishonesty. This finding replicates previous research on the importance of students' attitudes for understanding and reducing dishonest academic behaviours in institutions of higher learning (e.g., Bolin, 2004; Graham et al., 1994; Jensen et al., 2002; Jordan, 2001; Michaels \& Miethe, 1989; Rakovski \& Levy, 2007). These associations between students' perceptions and evaluations and their behaviours could lend support to the rational choice perspective that people behave in accordance with their subjective perceptions and evaluations (Bolin, 2004; Jensen et al., 2002; Whitley, 1998).

Of course, it is also possible that behaviours and attitudes may be correlated as a result of cognitive consistency processes (Bolin, 2004; Jensen et al., 2002). In line with the cognitive dissonance perspective, it can be argued that incongruence between students' beliefs that cheating is wrong and their dishonest academic behaviours will result in pressures to make these two elements consonant to avoid the negative affective consequences of attitude-behaviour inconsistency (Jensen et al., 2002; Whitley, 2001). Indeed, many college students who cheat invoke "neutralization" (or rationalization) techniques to reduce their cognitive dissonance by attributing their behaviours to external circumstances that justify their viola- 
tions of existing norms (e.g., Diekhoff et al., 1999; Haines et al. 1986; Jordan, 2001; Vandehey et al., 2007). Several researchers warn about this possibility (e.g., Bolin, 2004; Haines et al., 1986). Thus, it is very possible that students' perceptions and evaluations of academic dishonesty are the result of previous dishonest academic behaviours rather than the cause, or even that students' attitudes toward academic dishonesty and their dishonest behaviours are reciprocally determined (Bolin, 2004; Jensen et al., 2002). The results of the present investigation did not fully address the causality issue. Future research is needed with longitudinal designs to address causality more adequately.

Interestingly, our results revealed that the relationship between instrumental motives to study and academic dishonesty was a complex one, being moderated by self-efficacy beliefs. That is, students with a high score in the instrumental motives to study subscale were less likely to behave dishonestly when they had a high score in the self-efficacy scale, suggesting perhaps that they had greater confidence in their capabilities to achieve their academic goals without resorting to academic dishonesty. In line with Bandura's $(1986,1997)$ assertion regarding the potential direct, mediating, and moderating predictive utility of self-efficacy beliefs, we found that in addition to its direct effect, self-efficacy fulfilled a moderating role in the relationship between instrumental motives to study and academic dishonesty. Thus, consonant with the social learning theory (Bandura, 1977), it is possible to argue that high self-efficacy acted as a "protective factor" that interacted with instrumental motives to study to reduce the likelihood of academic dishonesty by keeping instrumentally oriented students motivated to try hard, persist, and achieve (Pintrich, 2003, p. 671).

Mounting theoretical and empirical evidence highlights the importance of students' self-efficacy beliefs in influencing their academic motivation and behaviour (for helpful reviews, see Murdock \& Anderman, 2006; Pajares, 1996; Pintrich, 2003; Schunk, 1991). Pintrich (2003) explains that "students who believe they are able and that they can and will do well are much more likely to be motivated in terms of effort, persistence, and behavior than students who believe they are less able and do not expect to succeed" (p. 671). Our examination of the moderating role of a motivational construct like self-efficacy answers a call for more studies that simultaneously assess indicators of goals that underlie learning and expectations for achieving these goals on dishonest academic behaviours (see Murdock \& Anderman, 2006). On the basis of our findings, we suggest that future research needs to move beyond simple main effects analyses to explore interactional models of academic dishonesty to advance our understanding of how different factors interact to generate different patterns of motivated behaviour.

Consistent with our theoretical expectations, results of the present study indicated that academic dishonesty was related negatively to the use of deep-level strategies and positively to the use of surface-level strategies. Similar patterns of results were reported by Anderman et al. (1998) in a sample of 285 middle school American students, and by Norton et al. (2001) in a sample of 267 third-year psy- 
chology students from four U.K. universities. Because the learning strategies students adopt influence the way they approach learning, the strategies result in qualitatively different learning outcomes (Arend, 2007; Saroyan, 2010). Why would the use of deep-level strategies be related to a lesser propensity to engage in acts of academic dishonesty? Deep strategies for learning involve deliberate efforts to use complex, higher-order cognitive and metacognitive strategies that require students to apply, analyze, synthesize, abstract, and evaluate course content with the intention of processing and making sense of the newly learned material (Anderman et al., 1998; Biggs, 1987, 1999; Jeffrey, 2009). Thus, utilizing such complex strategies properly requires a conscious, intentional effort on the part of the student. As well, there is reason to believe that students who use deep learning strategies and who perceive college as an opportunity for learning and personal growth may feel academic dishonesty is at odds with their goals of developing such meaningful knowledge structures through the adoption of complex cognitive activities and thought processes. Put differently, "the student who decides to expend the effort to use complex strategies and who truly values such strategies may feel that it is self-defeating to cheat" (Anderman et al., 1998, p. 85).

That Social Work students would be less likely to engage in dishonest academic behaviours is not a finding anticipated from the reviewed literature. The behavioural differences between Arts and Social Work students could be confounded by other factors not measured by the present study, such as workload or variations in discipline. Of course, the differences could also be an artifact of the sample design. As noted, the characteristics of our sample make it inappropriate to generalize our findings to the entire university population. Future research should extend the findings of the present study by using larger, randomly selected samples of students.

Another noteworthy and somewhat unexpected outcome of our study is the finding that the measure of academic dishonesty was not related to a student's demographic traits. Whereas previous research indicated that younger university students are more likely to cheat (e.g., Finn \& Frone, 2004; McCabe \& Treviño, 1997; Rakovski \& Levy, 2007; Vandehey et al., 2007), we found that age had no significant effect on academic dishonesty. Sex was also unrelated to academic dishonesty. As noted at the outset, the literature is mixed regarding whether male students are more likely to engage in dishonest academic behaviours than their female counterparts. Consistent with sex role socialization theory, we expected to find sex differences in academic dishonesty. Accordingly, variations in childhood socialization processes of boys and girls lead to differences in internalized normative expectations that result in attitudinal and behavioural differences between men and women. While past research on the relationship between sex and academic dishonesty is less than conclusive, our study adds to a body of recent work that shows non-significant results by students' sex (e.g., Chapman et al., 2004; Jordan, 2001; Pino \& Smith, 2003). This pattern of results seems to imply converging gender-role requirements in collegiate settings (Crown \& Spiller, 1998), resulting in women's behaviours becoming more similar to men's. This explanation has re- 
ceived some empirical support in the findings of prior research. For example, in a meta-analysis of research on sex differences in cheating, Whitley et al. (1999) found very small gender differences in cheating behaviour, suggesting male and female students are about equally likely to cheat. In a similar vein, Crown and Spiller (1998) reported considerable narrowing of the sex differences in cheating in studies published during the 1980s and 1990s. Based on a comparison of data collected in national surveys in 1963 and 1993, McCabe and Treviño (1996) found that gender differences in cheating narrowed over the 30-year period examined so that the amount of female cheating increased to become similar to that of their male counterparts, whose rate remained stable at a relatively high level.

Future investigation needs to expand the focus of research beyond sex differences in academic dishonesty by addressing a number of other interesting issues. For example, more research is needed on the social psychological mechanisms underlying female students' propensity to behave dishonestly despite internalized role requirements that orient them to be morally more conscious, responsible, and rule abiding than men (Ward \& Beck, 1990; Whitley et al. 1999). This area is particularly interesting given that earlier research on our part on the same sample of students suggests that female students judged dishonest academic behaviours more stringently than their male counterparts (Jurdi, Hage, \& Chow, 2011). Consistent with the cognitive dissonance perspective, it is reasonable to argue that this incongruity between their beliefs and their behaviours should lead female students to experience more negative affective responses to cheating than their male counterparts (Whitley, 2001). Further empirical confirmation is required in support of this hypothesis. Alternatively, the finding that there are sex differences in students' perceptions of academic dishonesty but not in their engagement in dishonest academic behaviours could imply that a certain degree of neutralization may be operating to allow female students to justify or rationalize acting in ways that are inconsistent with their held belief. Students' justifications for behaving dishonestly might ease negative feelings about themselves (Murdock \& Anderman, 2006). Indeed, previous work suggests women tend to hold themselves to higher moral standards than men do, and, as a result, they are more likely to neutralize their cheating and to justify cheating as necessary to deflect the shame and guilt over having cheated (e.g., Smith, Davy, Rosenberg, \& Haight, 2002). If so, we could expect female students to be more likely to invoke neutralizing or excusemaking strategies to explain or justify their dishonest academic behaviours. Future research should also address this possibility.

\section{LIMITATIONS AND FUTURE DIRECTIONS}

The present study has a few methodological limitations that must be acknowledged. Although participants were assured complete anonymity and confidentiality, bias resulting from self-report and social desirability may have influenced the results. Taken together, the predictors studied here accounted for less than half of 
the total variance in academic dishonesty. Clearly, many other possible correlates remain that deserve attention in future studies. Predictors considered important in the literature-for example, certainty of sanctions, severity of punishment, class environment, and student workload-were not measured in the survey instrument. Future research should consider these and other relevant factors, integrating them through a theoretical lens. To date, much of the research on academic dishonesty has been descriptive in nature and lacks an overarching, theoretically based framework (Bolin, 2004; Murdock \& Anderman, 2006). In many ways, this critique can be extended to the present undertaking. Regrettably, the survey instrument used here was not conceived with the intent of empirically testing particular theoretical or conceptual models, resulting in the omission of a number of theoretically relevant constructs necessary to test much of the available theoretical work.

What is lacking in the Canadian academic dishonesty literature is research to test the validity of theoretical models that examine the decision-making processes of students before they engage in acts of academic dishonesty. A theoretical model that is receiving increased validation in the American literature is the Theory of Planned Behaviour (Ajzen, 1991, 2002, 2006; Beck \& Ajzen, 1991; Whitley, 1998). According to this theory, attitudes toward behaviour, subjective norms, and perceived behavioural control influence a student's propensity to behave dishonestly through the effects that these attitudes have on intention. Future research should attempt to validate this theoretical framework using larger, randomly selected samples of students from universities across Canada. Of course, further efforts are also needed to develop a sound instrument to measure the various constructs of this theoretical framework using measures found to have strong reliability and validity.

Within these constraints, our study provides valuable insights into the individual, situational, and attitudinal factors underlying academic dishonesty in the Canadian classroom. Also, there is no theoretical or conceptual reason to believe that the underlying nature of the relationships between the predictors and students' extent of academic dishonesty would have been different had this study relied on a larger and more representative sample of students. It is indeed reassuring to find that our results are consistent with those of prior studies which used different samples.

\section{RECOMMENDATIONS}

Given the extent to which this sample of students' self-reported engaging in academic dishonesty, and the various individual, situational, and attitudinal factors associated with such behaviours, it is clear that the promotion and maintenance of academic integrity requires a balanced, coordinated, and comprehensive approach that focuses on prevention, detection, and penalty and that involves university administrators, faculty, and students (Carroll, 2001; Carroll \& Appleton, 2001; Christensen Hughes \& McCabe, 2006b; McCabe et al., 2001). We share the belief that a "catch-and-punish" approach alone will not work, arguing instead 
that a more effective way to address the problem of academic dishonesty involves "combining academic and policy decisions in a systematic, fair and coherent way" (Carroll \& Appleton, 2001, p. 4, 7).

That students' perceptions and evaluations of academic dishonesty and their perceptions of their peers' behaviours had such important associations with their propensity to behave dishonestly suggest that greater efforts are needed to communicate and explain specific ethical guidelines to students. Jackson, Levine, Furnham, and Burr (2002) call this "a strong situation," characterized by more effective dissemination of the significance of academic integrity and the implications of breaking academic rules by setting and enforcing strong standards of academic integrity (p. 1034). To encourage students' involvement in the deterrence and detection of academic dishonesty, it might be worth considering the development of a "modified honour code model" to foster academic ethics through honour pledges, peer reportage, and peer-run judiciary councils (Christensen Hughes \& McCabe, 2006b, p. 17). Penalizing students who cheat or plagiarize by using uniform and vigorous measures and publicizing estimates of such cases can send the message that behaving dishonestly results in serious consequences.

Last but not least, based upon the literature review and our own findings, it appears that helping students acquire the confidence and skills to do well has the potential of lowering academic dishonesty by fostering their self-efficacy and levels of interest and by encouraging them to understand the intrinsic value of education and learning. Consistent with this perspective, Summerlee and Chistensen Hughes (2010) succinctly note, "to drive learning, students should be motivated and empowered, and that means both building self-efficacy and setting the learning in the context of problems that are relevant, or have an intrigue or immediacy that makes investigating them and understanding them an absolute challenge" (p. 257). Thus, we propose that efforts should be directed at increasing students' test-taking, writing, and studying and time-management skills. Intervention strategies could focus on the design and implementation of cognitively engaging (yet sufficiently challenging) tasks and activities that promote students' competence, expertise, and skill and that encourage them to adopt deep approaches to learning combined with the provision of timely, accurate, and constructive instructional feedback to help them acquire the expertise needed to learn (Pintrich, 2003).

\section{NOTES}

1 The double-headed arrow suggests an association exits between students' dishonesty-related attitudes and behaviours, after controlling for other theoretically relevant factors. Finding associations between variables and ruling out alternative explanations are necessary but not sufficient conditions to establish causality. To firmly establish causality, we also need to ascertain temporal order. As with many other studies, the results of the present investigation did not fully address the causality issue because this research would require longitudinal designs. That is, there is need for a research design that allows us to show that students' attitudes toward academic dishonesty precede their deviant behaviour. 
2 Falsification was operationalized as any behaviour deliberately designed to gain academic advantage by misrepresentation (for instance, by falsifying records or dishonest excuse-making).

3 The "instrumental" factor score had a significant negative skew (i.e., the skewness statistic is greater than $|1|$ ). The skewed factor score was transformed using an inverse transformation. In turn, the peers' cheating behaviour variable had a positive skew (i.e., the skewness statistic is greater than $|1|$ ); as a result, the skewed variable was transformed using a log transformation. These transformations resulted in a considerable decrease in skewness in both measures.

4 Orthogonalization partials out the effect of all the preceding variables creating transformed variables that are uncorrelated with one another but are still correlated with the dependent variable. This procedure does not affect the estimation process or the final estimation as the predictor parameters have not been changed, only linearly transformed. However, it does affect the contribution of each individual orthogonal parameter because the order determines the other parameters against which it is orthogonalized. The order proposed for orthogonalization was based on causal ordering and the theoretical importance of the variables included in the analyses. The order presents the effect of a certain parameter after accounting for the effect of the previous ones.

5 It should be pointed out that Christensen Hughes and McCabe (2006b) used 25 survey items to measure academic dishonesty, whereas the survey instrument used in the present investigation included three types of dishonest academic behaviours. Their window of observation was "past year." The present study looked at students' dishonest academic behaviours during their tenure at university.

\section{REFERENCES}

Ajzen, I. (1991). The theory of planned behavior. Organizational Behavior and Human Decision Processes, 50, 179-211.

Ajzen, I. (2002). Perceived behavioral control, self-efficacy, locus of control, and the theory of planned behavior. Journal of Applied Social Psychology, 32(4), 665-683.

Ajzen, I. (2006). Theory of planned behavior diagram. Retrieved from http:/ / people.umass.edu/aizen/tpb.diag.html\#null-link

Anderman, E. M., Griesinger, T., \& Westerfield, G. (1998). Motivation and cheating during early adolescence. Journal of Educational Psychology, 90(1), 84-93.

Angell R. (2006). The relationship of impulsiveness, personal efficacy, and academic motivation to college cheating. Lance College Student Journal, 40(1), 118-131.

Arend, B. (2007). Course assessment practices and student learning strategies in online courses. Journal for Asynchronous Learning Networks, 11(4), 3-17.

Bandura, A. (1977). Social learning theory. Englewood Cliffs, NJ: Prentice Hall.

Bandura, A. (1986). Social foundations of thought and action: A social cognitive theory. Englewood Cliffs, NJ: Prentice Hall. 
Bandura, A. (1989). Human agency in social cognitive theory. American Psychologist, 44(9), 1175-1184.

Bandura, A. (1997). Self-efficacy: The exercise of control. New York, NY: Freeman.

Beck, L., \& Ajzen, I. (1991). Predicting dishonest actions using the theory of planned behaviour. Journal of Research in Personality, 25, 285-301.

Biggs, J. B. (1987). Student approaches to learning and studying. Hawthorne, Australia: Australian Council for Educational Research.

Biggs, J. B. (1999). What the student does: Teaching for enhanced learning. Higher Education Research \& Development, 18(1), 57-75.

Bloodgood, J. M., Turnley, W. H., \& Mudrack, P. (2008). The influence of ethics instruction, religiosity, and intelligence on cheating behavior. Journal of Business Ethics, 82, 557-571.

Bogler, R., \& Somech, A. (2002). Motives to study and socialization tactics among university students. Journal of Social Psychology, 142(2), 233-248.

Bolin, A. U. (2004). Self-control, perceived opportunity, and attitudes as predictors of academic dishonesty. Journal of Psychology, 138(2), 101-114.

Bowers, W. J. (1964). Student dishonesty and its control in college. New York, NY: Bureau of Applied Social Research, Columbia University.

Carpenter, D. D., Harding, T. S., Finelli, C. J., Montgomery, S. M., \& Passow, H. J. (2006). Engineering students' perceptions of and attitudes towards cheating. Journal of Engineering Education, 95(3), 181-194.

Carroll, J. (2001). What kind of solutions can we find for plagiarism? Report prepared for The Higher Education Academy. Retrieved from http: / / www.gla.ac.uk / media/media_13513_en.pdf

Carroll, J., \& Appleton, J. (2001). Plagiarism: A good practice guide. Report prepared for the Joint Information Systems Committee. Retrieved from http:/ / www. jisc.ac.uk/uploaded_documents/brookes.pdf

Chapman, J. K., Davis, R., Toy, D., \& Wright, L. (2004). Academic integrity in the business school environment: I'll get by with a little help from my friends. Journal of Marketing Education, 26(3), 236-249.

Christensen Hughes, J. M., \& McCabe, D. L. (2006a). Understanding academic misconduct. Canadian Journal of Higher Education, 36(1), 49-63.

Christensen Hughes, J. M., \& McCabe, D. L. (2006b). Academic misconduct within higher education in Canada. Canadian Journal of Higher Education, 36(2), $1-21$.

Côte, J. E., \& Allahar, A. L. (2007). Ivory tower blues: A university system in crisis. Toronto, Buffalo, London: University of Toronto Press.

Crown, D. F., \& Spiller, M. S. (1998). Learning from the literature on collegiate cheating: A review of empirical research. Journal of Business Ethics, 17, 683-700. 
Davy, J. A., Kincaid, J. F., Smith, K. J. \& Kenneth, J. (2007). An examination of the role of attitudinal characteristics and motivation on the cheating behaviour of business students. Ethics \& Behavior, 17(3), 281-302.

Diekhoff, G. M., LaBeff, E. E., Shinohara, K., \& Yasukawa, H. (1999). College cheating in Japan and the United States. Research in Higher Education, 40(3), 343-353.

Eison, J. (1981). A new instrument for assessing students' orientation towards grades and learning. Psychological Reports, 48, 919-924.

Eison, J., Pollio, H., \& Milton, O. (1986). Educational and personal characteristics of four different types of learning and grade oriented students. Contemporary Educational Psychology, 11(1), 54-67.

Eskridge, C., \& Ames, G. A. (1993). Attitudes about cheating and self-reported cheating behaviors of criminal justice majors and noncriminal justice majors: A research note. Journal of Criminal Justice Education, 4, 65-78.

Evans, E. D., \& Craig, D. (1990). Teacher and student perceptions of academic cheating in middle and senior high schools. Journal of Educational Research, 84, 44-52.

Fass, R. A. (1990). Cheating and plagiarism. In W. M. May (Ed.), Ethics and higher education (pp. 170-183). New York: Macmillan.

Finn, K. V., \& Frone, M. R. (2004). Academic performance and cheating: Moderating role of school identification and self-efficacy. Journal of Educational Research, 97(3), 115-122.

Ford, R. C., \& Richardson, W. D. (1994). Ethical decision making: A review of the empirical literature. Journal of Business Ethics, 13, 205-221.

Genereux, R. L., \& McLeod, B. A. (1995). Circumstances surrounding cheating: A questionnaire study of college students. Research in Higher Education, 36(6), 687-704.

Golub, G. H., \& Van Loan, C. F. (1996). Matrix Computations (2nd ed.). Baltimore \& London: Johns Hopkins University Press.

Graham, M. A., Monday, J., O'Brien, K., \& Steffen, S. (1994). Cheating at small colleges: An examination of student and faculty attitudes and behaviors. Journal of College Student Development, 35, 255-260.

Grimes, P. W. (2004). Dishonesty in academics and business: A cross-cultural evaluation of student attitudes. Journal of Business Ethics, 49(3), 273-290.

Haines, V. J., Diekhoff, G. M., LaBeff, E. E., \& Clark, R. E. (1986). College cheating: Immaturity, lack of commitment, and the neutralizing attitude. Research in Higher Education, 25(4), 342-354.

Harding, T. S., Carpenter, D. D., Finelli, C. J., \& Passow, H. J. (2004). Does academic dishonesty relate to unethical behavior in professional practice? An exploratory study. Journal of Ethics and Social Values, 10(2), 311-324.

Huelsman, M. A., Piroch, J., \& Wasieleski, D. (2006). Relation of religiosity with academic dishonesty in a sample of college students. Psychological Reports, 99, 739-742. 
Jackson, C. J., Levine, S. Z., Furnham, A., \& Burr, N. (2006). Predictors of cheating behavior at a university: A lesson from the psychology of work. Journal of Applied Social Psychology, 32(5), 1031-1046.

Jeffrey, L. M. (2009). Learning orientations: Diversity in higher education. Learning and Individual Differences, 19, 195-208.

Jensen, L. A, Arnett, J. J., Feldman, S. S., \& Cauffman, E. (2002). It's wrong, but everybody does it: Academic dishonesty among high school and college students. Contemporary Educational Psychology, 27, 209-228.

Jordan, A. E. (2001). College student cheating: The role of motivation, perceived norms, attitudes, and knowledge of institutional policy. Ethics and Behavior, 11(3), 233-247.

Jurdi, R., Hage, H. S., \& Chow, H. P. H. (2011). What behaviours do students consider academically dishonest? Findings from a survey of Canadian undergraduate students. Social Psychology of Education. doi: 10.1007 / s11218-011-9166-y

Kelley, R. M., Young, M., Denny, G., \& Lewis, C. (2005). Liars, cheaters, and thieves: Correlates of undesirable character behaviours in adolescents. American Journal of Health Education, 36(4), 194-201.

Kerkvliet, J. (1994). Cheating by economics students: A comparison of survey results. Journal of Economic Education, 25(2), 121-133.

Kidwell, L. A., Wozniak, K., \& Laurel, J. P. (2003). Student reports and faculty perceptions of academic dishonesty. Teaching Business Ethics, 7(3), 2005-2214.

Kohlberg, L. (1973). The claim to moral adequacy of a highest stage of moral judgment. Journal of Philosophy, 70(18), 630-646.

LaBeff, E., Clark, R., Haines, V., \& Diekhoff, G. (1990). Situational ethics and college student cheating. Sociological Inquiry, 60(2), 190-198.

Leming, J. S. (1980). Cheating behavior, subject variables, and components of the internal-external scale under high and low risk conditions. Journal of Educational Research, 74(2), 83-87.

Lindblom-Ylänna, S. (2010). Student's approaches to learning and their perceptions of the teaching-learning environment. In J. Christensen Hughes \& J. Mighty (Eds.), Taking stock: Research on teaching and learning in higher education (pp. 63-80). Kingston, ON: McGill-Queen's University Press.

McCabe, D. L., Butterfield, K. D., \& Treviño, L. K. (2006). Academic dishonesty in graduate business programs: Prevalence, causes, and proposed action. Academy of Management Learning \& Education, 5(3), 294-305.

McCabe, D. L., \& Treviño, L. K. (1993). Academic dishonesty: Honour codes and other contextual influences. Journal of Higher Education, 64(5), 522-538.

McCabe, D. L., \& Treviño, L. K. (1995). Cheating among business students: A challenge for business leaders and educators. Journal of Management Education, 19(2), 205-218. 
McCabe, D. L., \& Treviño, L. K. (1996). What we know about cheating in college. Change, 28(1), 29-33.

McCabe, D. L., \& Treviño, L. K. (1997). Individual and contextual influences on academic dishonesty: A multicampus investigation. Research in Higher Education, 38(3), 379-396.

McCabe, D. L., Treviño, L. K., \& Butterfield, K. D. (2001). Cheating in academic institutions: A decade of research. Ethics and Behaviour, 11(3), 219-233.

Michaels, J. W., \& Miethe, T. D. (1989). Applying theories of deviance to academic cheating. Social Science Quarterly, 70(4), 870-885.

Murdock, T. B., \& Anderman, E. M. (2006). Motivational perspectives on student cheating: Toward an integrated model of academic dishonesty. Educational Psychologist, 41(3), 129-145.

Murdock, T. B., Hale, N. M., \& Weber, M. J. (2001). Predictors of cheating among early adolescents: Academic and social motivations. Contemporary Educational Psychology, 26, 96-115.

Newstead, S. E., Franklyn-Stokes, A., \& Arrnstead, P. (1996). Individual differences in student cheating. Journal of Educational Psychology, 88, 229-241.

Nonis, S., \& Swift, C. (2001). An examination of the relationship between academic dishonesty and workplace: A multicampus investigation. Journal of Education for Business, 77(2), 69-77.

Norton, L. S., Tilley, A. J., Newstead, S. E., \& Franklyn-Stokes, A. (2001). The pressures of assessment in undergraduate courses and their effect on student behaviours. Assessment \& Evaluation in Higher Education, 26(3), 269-284.

Office of Research Planning. (2008). Facts 2008. Retrieved from http:/ / www. uregina.ca/orp/ factbook.shtml

Pajares, F. (1996). Self-efficacy beliefs in academic settings. Review of Educational Research, 66(4), 543-578.

Pallant, J. (2005). SPSS survival manual: A step by step guide to data analysis using SPSS for Windows (2nd ed.). NY: Open University Press.

Perry, A. R., Kane, K. M., Bernesser, K. J., \& Spicker, P. T. (1990). Type A behaviour, competitive achievement-striving, and cheating among college students. Psychological Reports, 66(2), 459-465.

Pino, N. W., \& Smith, W. L. (2003). College students and academic dishonesty. College Student Journal, 37(4), 490-500.

Pintrich, P. R. (2003). A motivational science perspective on the role of student motivation in learning and teaching contexts. Journal of Educational Psychology, 95(4), 667-686.

Rakovski, C. C. \& Levy, E. S. (2007). Academic dishonesty: Perceptions of business students. College Student Journal, 41(2), 466-81. 
Rettinger, D. A., \& Kramer, Y. (2009). Situational and personal causes of student cheating. Research in Higher Education, 50(39), 293-313.

Richardson, J. T. (1990). Reliability and replicability of the Approaches to Studying Questionnaire. Studies in Higher Education, 15(2), 155-168.

Saroyan, A. (2010). Research on student learning: Converging and diverging messages. In J. Christensen Hughes \& J. Mighty (Eds.), Taking stock: Research on teaching and learning in higher education (pp. 95-109). Kingston, ON: McGill-Queen's University Press.

Schunk, D. H. (1991). Self-efficacy and academic motivation. Educational Psychologist, 26(3/4), 207-231.

Schwarzer, R., \& Jerusalem, M. (1995). Generalized self-efficacy scale. In J. Weinman, S. Wright, \& M. Johnston (Eds.), Measures in health psychology: A user's portfolio (pp. 35-37). Windsor, UK: NFER-Nelson.

Sims, R. L. (1993). The relationship between academic dishonesty and unethical business practices. Journal of Education for Business, 69, 207-211.

Smith, K. J., Davy, J. A., Rosenberg, D. L., \& Haight, G. T. (2002). A structural modeling investigation of the influence of demographic and attitudinal factors and in-class deterrents on cheating behaviors among accounting majors. Journal of Accounting Education, 20, 45-65.

Smyth, M. L., \& Davis, J. R. (2003). An examination of student cheating in the two-year college. Community College Review, 31, 17-32.

Statistics Canada. (2009). University enrolment, 2007/2008. The Daily, July 28. Statistics Canada Catalogue no. 11-001-XIE. p. 1-9. Retrieved from http:/ / www. statcan.gc.ca/ daily-quotidien/090713/t090713a1-eng.htm

Statistics Canada [Postsecondary Student Information System]. (2010). Description for Chart 3. Age distribution of university students, by program level, 2007. In M. Dale, Trends in the age composition of college and university students and graduates. Education Matters: Insights on Education, Learning and Training in Canada, 8(2), December 13. Statistics Canada Catalogue no. 81-004-X. Retrieved from http:/ / www.statcan.gc.ca/ pub / 81-004-x/ 2010005/ article/ 11386-eng.htm

Summerlee, A. J., \& Christensen Hughes, J. (2010). Pressures for change and the future of university education. In J. Christensen Hughes \& J. Mighty (Eds.), Taking stock: Research on teaching and learning in higher education (pp. 243-260). Kingston, ON: McGill-Queen's University Press.

Tabachnick, B. G., \& Fidell, L. S. (2007). Using multivariate statistics (5th ed.). Boston: Pearson.

Tibbetts, S. G. (1997). Gender differences in students' rational decisions to cheat. Deviant Behavior, 18(4), 393-414.

Vandehey, M. A., Diekhoff, G. M., \& LaBeff, E. E. (2007). College cheating: A twenty-year follow-up and the addition of an honor code. Journal of College Student Development, 48(4), 468-480. 
Ward, D. A., \& Beck, W. L. (1990). Gender and dishonesty. Journal of Social Psychology, 130(3), 333-339.

Weiss, J., Gilbert, K., Giordano, P., \& Davis, S. F. (1993). Academic dishonesty, type A behavior, and classroom orientation. Bulletin of the Psychonomic Society, 31(2), 101-102.

Whitley, B. E. (1998). Factors associated with cheating among college students: A review. Research in Higher Education, 39(3), 235-274.

Whitley, B. E. (2001). Gender differences in affective responses to having cheated: The mediating role of attitudes. Ethics \& Behavior, 11(3), 249-259.

Whitley, B. E., \& Keith-Spiegel, P. (2002). Academic dishonesty: An educator's guide. Mahwah, NJ: Lawrence Erlbaum Associates.

Whitley, B. E., Nelson, A. B., \& Jones, C. J. (1999). Gender differences in cheating attitudes and classroom cheating behavior: A meta-analysis. Sex Roles, $41(9 / 10), 657-680$.

\section{CONTACT INFORMATION}

Dr. Rozzet Jurdi

Department of Sociology and Social Studies

Faculty of Arts

University of Regina

Regina SK S4S 0A2 Canada

rozzet.jurdi@uregina.ca.

Rozzet Jurdi is an Associate Professor in Sociology and Social Studies at the University of Regina. Her major teaching and research interests are in the areas of research methodology and statistics, survey design, demography and population studies, sociology of education, and philosophy of science.

H. Sam Hage is a PhD Candidate in Sociology at the University of Regina. His major research interests are in the areas of research methodology and statistics, survey design, sociology of education, and environmental sociology.

Henry P. H. Chow is a Professor and Graduate Program Coordinator in the Department of Sociology and Social Studies at the University of Regina. He is also an Adjunct Associate Professor of Sociology at the University of Calgary. His major teaching and research interests are in the areas of criminal justice, ethnic studies, social gerontology, sociology of religion, and sociology of education.

\section{ACKNOWLEDGEMENTS}

The survey was conducted with the financial support of the Department of Sociology and Social Studies at the University of Regina. We wish to thank the three anonymous reviewers for several useful suggestions that were incorporated into this manuscript. 